\title{
O PRINCÍPIO DA TRANSPARENCIA E O APROFUNDAMENTO DOS CARACTERES FUNDAMENTAIS DO DIREITO ADMINISTRATIVO
}

\author{
MAREN GUIMARÃES TABORDA* \\ "Não pode ser de outra maneira. Digo, pois, que há duas espécies de \\ movimento: o de alteração e o de translação." \\ (Platão, Teeteto, 181 d.) \\ Introdução. I - DEVERES DE TRANSPARENNCIA E DIREITOS DE PAR- \\ TICIPAÇĀO. I.I Natureza e conteúdo do Princípio da Transparência; 1.2 \\ Participação pelo Procedimento Administrativo. II - CONCRETIZAÇÕES \\ DA TRANSPARENCIA ADMINISTRATIVA NO BRASIL. 2.1 A lei de pro- \\ cesso administrativo Brasileira; 2.1.1 Os principios e regras fundamentais; \\ 2.1.2 Participação dos interessados e motivação dos atos administrativos; \\ 2.2 Direito de obter informações e certidões; 2.3 A lei de responsabilidade
} fiscal. Conclusão.

\section{Introdução}

A realidade da globalização, principalmente na Europa, ao pôr em xeque a noção de soberania nacional, modifica a estrutura do direito administrativo de cada país ligado, no essencial, ao Estado nacional - implicando sua mutação interna e externa. ${ }^{1}$ A verificação das mutaçōes que são produzidas nos direitos da Administração nos países europeus obriga a relativizar o impacto da integração neste domínio, porque o surgimento de fontes supra-estatais de direito administrativo, conquanto constitua,

* Procuradora do Município de Porto Alegre. Professora de História do Direito e de Direito Romano na PUCRS e na UNISINOS. Mestre em Teoria do Direito e do Estado pela UFRGS.

1 Cf. MARCOU, Gérard. Intégration juridique et logiques nationales. In: MARCOU. Gérard et alli. Les Mutations du Droit de L'Administration en Europe.Pluralisme et convergences. Paris: Editions L'Harmattan, 1995, p.11.

R. Dir. Adm.,

Rio de Janeiro, 230: 251-279,

Out./Dez. 2002 
para todos os países da União Européia, uma verdadeira mutação, imputável à evolução do Estado, não esgota o âmbito das transformações. pois se verifica, nos últimos anos, que os direitos administrativos também se transformam de maneira relativamente autônoma, em que a influência do direito supra-estatal europeu é assaz limitada.

Como tendências comuns dessas transformações internas do direito administrativo nos países europeus, e, por conseguinte, nos demais países de sistema jurídico romano-germânico, podem ser apontadas mudanças institucionais, ${ }^{2}$ e a tendência de se reforçarem as bases constitucionais do direito administrativo, com a subordinação deste aos direitos fundamentais definidos pela Constituição, ${ }^{3}$ de modo que passa a ser visto "direito constitucional concretizado" . Isso é assim porque a própria "noção do direito administrativo pressupõe a prévia organização política do Estado (...) que é a sua matriz constitucional", ou seja, a Constituição é a "fonte e a essência do poder político". 5 A Administração, então, se deixa definir como "o exercício do poder executivo sob um regime de poder público", pelas suas prerrogativas e sujeições exorbitantes do direito comum. "As tendências das Constituições modernas são, por conseguinte, deslocar o centro de gravidade da ordem jurídica. transformando o Estado de simples garantidor da liberdade individual em guardião da segurança social, de modo que se ampliam os serviços públicos e, por efeito reflexo, expande-se o direito administrativo, "instrumento por excelência da intervenção do Estado no domínio econômico e social". 7 Desta forma, "o direito constitucional e o direito administrativo se imbricam e se completam na prestação efetiva do estado de direito" . ${ }^{8}$ Daí. os princípios gerais do direito administrativo são suscetíveis de serem deduzidos de disposições e princípios de direito constitucional, como no caso em que a Corte Administrativa Federal Alemã desenvolveu a teoria da anulação de atos administrativos a partir de princípios constitucionais antagônicos - legalidade ( $\mathrm{Ge}$ setżmässigkeit) e proteção à confiança (Vertrauensschutz) - integrantes, os dois, do principio do 'Estado de Direito'. Essa corrente de pensamento se reconduz ao consenso obtido no pós-guerra em torno de certos valores centrais para os ordenamentos jurídicos modernos. como os da liberdade e da igualdade (conteúdo material da Justiça e do pluralismo político), que pretendem. em última instância, facilitar e tornar possível o desenvolvimento integral da pessoa e o exercício efetivo e real de

MARCOU, (nota 1), p. 57.

MARCOU. (nota 1), p. 58.

4 A expressão é, originariamente, de Fritz Werner, mas usada correntemente no direito alemão, como se vê em MAURER, Harmut. Droit Administrafif Allemand. Paris: LGDJ, 1994, p. 72.

5 CAIO TÁCITO. Bases Constitucionais do Direito Administrativo. RDA n 166, out./dez. 1986. p. 39.

6 Cf. VEDEL, Georges. Droit Administratif. Tomo I. Paris: PUF, 1958, p. 23.

7 CAIO TÁCITO, (nota 5), p. 41. Assevera. ainda, o autor que o "papel do Estado, que se exprimia em deveres negativos (dever de não fazer ou não perturbar) e na garantia do livre exercício dos direitos individuais. passa a assumir deveres positivos (obrigaçōes de fazer), a que correspondem pretensōes dos administrados".

8 CAIO TÁCITO, (nota 5), p. 43. 
sua dignidade. Tais valores constituem e fundam os ordenamentos jurídicos, sob forma de princípios constitucionais, explícitos ou implícitos, e adquiriram. no direito público, "um vigor que nunca tinham possuído, notadamente na configuração da coerência e da consistência do sistema. As outras normas são sempre a eles necessariamente reconduzidas e são eles que orientam sua interpretação". ${ }^{9}$ e o próprio sistema jurídico passa a ser concebido como o resultado da regra de justiça - princípio da igualdade.

A transparência administrativa constitui uma mutação fundamental no direito da Administração, cujo princípio se impõe como um dos princípios gerais do direito, ao inverso da tradição do segredo administrativo, quer seja fundada na herança napoleônica ou sobre o princípio da responsabilidade ministerial. O princípio ou dever de transparência comporta outras modalidades, como o direito de participar no procedimento de decisão em certos domínios, a obrigação para a Administração de publicar as informações pertinentes, a obrigação de motivar os atos administrativos individuais e o direito de acesso aos bancos de dados. Procedimento e motivação dos atos administrativos, então, são, já há algum tempo, os territórios onde se mede a transparência da ação administrativa. A transparência está, em última instância, relacionada à própria idéia de democracia porque esta, além de ser o governo do povo - governo direto, governo controlado pelo povo, governo representativo do povo -, é o "regime do poder visível", isto é, "o governo do poder público em público", ao contrário dos estados autocráticos, em que o grau mais alto do poder político - o poder de tomar decisões obrigatórias para todos os cidadãos - coincide com "a concentração máxima da esfera do príncipe"..$^{10}$

No Brasil, grande é a tarefa da transparência administrativa, principalmente tendo-se em vista o peso da burocracia e da tradição do segredo na formação da ordem nacional. É sabido que o Estado brasileiro se constituiu como ordem jurídica antes de constituir-se como nação, seguindo a uma longa tradição histórica que remonta à própria formação do Estado Português. cujas bases foram o patrimonialismo, o centralismo monárquico, o estamento de feição burocrática e a idéia romana de que o princípe é legibus solutus. " Assim, a colonização brasileira foi obra do Estado, de forma que a organização administrativa precedeu ao fluxo das populaçōes: "a criação da realidade pela lei, pelo regulamento". ${ }^{12}$ O Estado, então, não foi sentido como o protetor dos interesses da população, o defensor das atividades dos particulares, mas como "um monstro sem alma. o titular da violência, o impiedoso cobrador de impostos" e existiu na colônia antes que ela tivesse povo. ${ }^{13}$ Nas várias fases

y COUTO E SILVA. Almiro. Os individuos e o Estado na realização de tarefas públicas. Informação por correio eletrônico: http://www.ufrgs.br/mestredir/. p. 25.

10 BOBBIO, Norberto. Estado, Governo e Sociedade - Para uma teoria geral da política. $4^{2}$. ed., São Paulo: Paz e Terra, 1992. p.

11 CF. FAORO, Raymundo. Os Donos do Poder. Formação do Patronato Político Brasileiro. Vol.

1. Porto Alegre: Editora Globo. 1976, pp. 1 a 15.

12 FAORO, (nota 11), p. 120.

13 FAORO, (nota 11), p. 165. 
políticas brasileiras, o traço comum foi o autoritarismo e a centralização burocrática, de modo que os governantes sempre se comportaram como "donos do poder". Estas práticas foram reforçadas com a tradição do segredo administrativo - permanentemente presente - e a perseguição política, principalmente nos regimes ditatoriais, de que são exemplos a ditadura de Vargas e a ditadura militar que se estabeleceu no País após 1964.

Durante os governos militares. informações colhidas em fontes de discutível idoneidade e por meio escusos "ou mesmo fabricadas pela paranóia de órgãos represssivos, viram-se incorporadas a registros oficiais ou paraoficiais e passaram a fornecer critérios de avaliação para a imposição de medidas punitivas ou discriminatórias" e, por óbvio, os interessados jamais tiveram acesso aos dados constantes dos registros. ${ }^{14} \mathrm{O}$ retorno à ordem democrática teve tendência a assegurar os direitos fundamentais, com a instituição de vários remédios processuais utilizáveis contra sua respectiva violação. Um desses direitos é a preservação da intimidade, de modo que a coleta e "o armazenamento de dados atinentes a uma pessoa, à revelia dela e sem controle de sua parte", ${ }^{15}$ constituiu uma invasão de privacidade. Desta forma, a ninguém deve ser negado o conhecimento do que os outros sabem ou supõem saber a seu respeito, nem a possibilidade de constestar a veracidade de tais informações ou, se for o caso, o direito de retificar o respectivo teor: todos têm "direito à verdade a respeito de si próprio". ${ }^{16}$

Isto posto. na Constituição Federal de 1988 foi inscrita uma série de princípios e regras tendentes a assegurar os direitos fundamentais dos cidadãos e os deveres de transparência do Estado, que, em última instância, decorrem da própria noção do que seja "Estado Democrático de Direito". Daí o princípio da transparência estar, inicialmente, concretizado na Constituição Federal, através do art. $5^{\circ}$, incisos XXXIII, XXXIV e LXXII, que asseguram a todos o direito de receber dos órgãos públicos informações (dados) de interesse particular ou de interesse coletivo ou geral, ressalvadas aquelas cujo sigilo seja indispensável à segurança da sociedade e do Estado, o direito de petição aos órgãos públicos, em defesa de direitos, ilegalidade ou abuso de poder e à obtenção de certidōes em repartições públicas, para a defesa de direitos e esclarecimentos de situações de interesse geral, bem como o direito de impetrar habeas data para assegurar o conhecimento de informações pessoais constantes de registros ou banco de dados de órgãos públicos e para retificação de dados. Em segundo lugar, a Lei $\mathbf{n}^{\circ} 9.784 / 99$, que regula o processo administrativo, concretizou a transparência administrativa em uma de suas direções mais fortes, a saber, a que exige a participação dos cidadãos no procedimento administrativo e a que obriga as autoridades administrativas a motivarem suas decisões. Finalmente, a Lei Complementar $n^{\circ} 101 / 00$, que dispõe sobre a Responsabilidade Fiscal, também

14 CF. BARBOSA MOREIRA. José Carlos. O Habeas data brasileiro e a sua lei regulamentadora. RDA. n²11. jan./mar. 1998. p. 49.

15 BARBOS MOREIRA. (nota 14), p. 49

16 FERREIRA FILHO, Manoel Gonçaives. Comentários à Constituiçâo Brasileira de 1988, Sâo Paulo. 1990. p. 81, apud BARBOSA MOREIRA, (nota 14). p. 50. 
realiza, direta ou indiretamente, o princípio da transparência administrativa. porquanto obriga os administradores públicos não só a emitirem declarações de responsabilidade fiscal como também a permitirem o acesso público a essas informações. Convém, então, estudar o alcance e conteúdo do princípio da transparência e suas concretizações no Brasil.

\section{I- Deveres de transparência e direitos de participação}

\section{I. Natureza e conteúdo do Princípio da Transparência}

Não há uma definição unitária do que sejam 'princípios jurídicos ${ }^{17}$ e. assim, eles podem ser: a) fundamentos, critérios para a justificação de uma ordem (Esser): b) pensamento diretor de uma regulação jurídica existente ou possível (Larenz); c) prescrições indiretamente ligadas a valores, fins, idéias e topoi (lugares argumentativos) a serem institucionalmente determinados (Canaris); d) modos abertos de argumentação (standards) que não determinam vinculativamente uma decisão, mas somente contêm fundamentos que devem ser conjugados com outros fundamentos provenientes de outros princípios (Dworkin) e, e) espécie de normas jurídicas por meio das quais são estabelecidos deveres de otimização, aplicáveis em vários graus, segundo as possibilidades normativas e fáticas (Alexy). Os princípios, ao contrário das regras, são normas jurídicas vagas e indeterminadas, que carecem de mediações concretizadoras, impositivas de uma otimização compatível com vários graus de concretização, comportando uma série infinita de aplicações. Os princípios não se aplicam automática e necessariamente quando as condições previstas como suficientes para sua aplicação se manifestem e apresentam uma dimensão de peso, ou importância, que não existe em relação às regras. Sendo os princípios jurídicos pensamentos diretores de uma regulação jurídica existente ou possível, não constituindo, por si mesmos, regras suscetíveis de aplicação, necessitam da concreção

17 Sobre os Princípios, ver: J.J.Gomes Canotilho. Direito Constitucional. Coimbra:Almedina, 1993, pp. 166 e ss; Eros Roberto Grau. A Ordem Econômica na Constituição de 1988: Interpretação e Crítica. São Paulo:RT,1991, passim; Ronald Dworkin. Los Derechos cn Serio. Barcelona:Ariel, 1989, capítulos 1, 2 e 3 e? Es el derecho un sistema de reglas? Cuadernos de Crítica 5, Instituto de Investigaciones Filosofficas. Universidad Autonoma de Mexico, 1977; Robert Alexy. Derecho $Y$ Razon Practica. Mexico: Distribuciones Fontamara, 1993 e Teoria de los Derechos Fundamentales, Madrid: Centro de Estudios Constitucionales, 1997; Judith Martins-Costa. A Boa fé no Direito Privado. São Paulo: Revista dos Tribunais. 1999, passim; Claus-Wilhelm Canaris. Pensamento Sistemático e Conceito de Sistema na Ciência do Direito. Lisboa: Fundaçāo Calouste Gulbenkian. 1989: Karl Larenz. Metodologia da Ciência do Direito. Lisboa: Fundação Calouste Gulbenkian. 1989. Capítulo V: Luis Díez-Picazo. Experiencias jurídicas y teoria del derecho. Barcelona: Ariel. 1993, Capítulo VIII: Josef Esser. Principio y Norma en la Elaboración Jurisprudencial del Derecho Privado. Barcelona: Bosch, 1961, passim:Elias Grossmann. Os Principios Jurídicos em Robert Alexy. UNISINOS. Dissertação de Mestrado. 2000, inédita, passim; Humberto Bergmann Ávila. A distinção entre princípios e regras e a redefinição do dever de proporcionalidade. Revista de Direito Administrativo $\mathrm{n}^{\circ}$ 215. jan.mar/1999, pp.157-179. entre outros. 
operada pelas cláusulas gerais. Os princípios servem, assim, como critério unificador. permitindo a recondução de uma série de casos particulares a um padrão relativamente unitário, viabilizando, dessa forma, a introdução de um critério de racionalidade em certo sistema jurídico.

Neste estudo, adota-se. principalmente, a concepção de Alexy, para considerar que as normas de Direito Fundamental têm dupla natureza: ou são normas-regra ou normas-princípio. ${ }^{18}$ Advém daí que os princípios são normas que ordenam que algo seja realizado na maior medida possível. dentro das possibilidades jurídicas e reais existentes. Mandatos de otimização. são caracterizados pelo fato de poderem ser cumpridos em diferentes graus. O âmbito das possibilidades jurídicas é determinado pelos princípios e regras opostos. Regras são normas que só podem ser cumpridas ou não, e contêm determinações no âmbito do fático e juridicamente possível, de modo que a diferença entre regras e princípios é qualitativa e não de grau. Toda norma ou é uma regra ou é um princípio e. no caso do conflito entre princípios, a distinção se torna clara. pois. aí, há a dimensão do peso ou importância: o conflito deve ser solucionado através de uma ponderação de princípios opostos. Nestes casos, os interesses são do mesmo grau e se trata de ponderar qual deles possui maior peso no caso concreto. ${ }^{19}$ Assim, os contlitos de regras são solucionados introduzindo-se uma cláusula de exceção, que elimina o conflito declarando uma delas inválida. $\mathrm{O}$ conceito de validade não é graduável. vale também a consequiência jurídica e os critérios são o da especialidade, o cronológico e o da hierarquia. Nas colisões de principios, um tem que ceder diante do outro, e como os princípios têm diferente peso, em certas circunstâncias, um deles tem precedência (princípio com mais peso). Se uma norma de direito fundamental entra em colisão com o princípio oposto, então a possibilidade jurídica de realização da norma de direito fundamental depende do princípio oposto.

Existe também uma conexão muito estreita entre a teoria dos princípios e o preceito da proporcionalidade e seus três preceitos parciais de adequação (alcançar

18 ALEXY. Robert. Teoria de los Derechos Fundamentales. Madrid: Centro de Estudios Constitucionales. 1997, pp. 111 e ss.

19 A distinção entre regras e princípios é importante porque constitui a base da fundamentação iusfundamental e é uma chave para a solução de problemas centrais da dogmática dos Direitos Fundamentais. A distinção, ademais. fornece uma teoria adequada dos limites. uma teoria satisfaIória da colisão e uma teoria suficiente acerca do papel que tem os Direitos Fundamentais em um sistema jurídico. Constitui, também, um marco de uma teoria normativo-material dos Direitos Fundamentais e. com isso, o ponto de partida para responder a pergunta acerca da possibilidade e dos limites de racionalidade no âmbito dos Direitos Fundamentais. Esta distinção entre regras e princípios é uma distinção entre tipos de normas e os critérios podem ser: a) generalidade (princípios alto: regras, baixo): c) determinabilidae dos casos de aplicação (Esser): c) forma de sua gênesis: Shuman (normas criadas e nurmas desenvolvidas): d) caráter explícito do conteúdo valorativo (Canaris): e) referência a uma idéia de Dircito (Larenz); f) legitimidade suprema (HJ Wolf): g) importância para o ordenamento juridico: i) fundamento de regras ou regras em si mesmo (Esser); h) normas de argumentação ou comportamento (Grossi). Outras teses advogan que: a) não é possível a distinção: b) a diferença é de grau (generalidade é o critério decisivo): c) a diferença não é de grau mas qualitativa. 
o resultado esperado), necessidade (aplicação do meio mais benigno) e proporcionalidade em sentido estrito (juízo sobre o equilíbrio do meio em relação ao fim), porque: a) os princípios são mandatos de otimização com respeito a possibilidades fáticas e jurídicas, de modo que a ponderação (proporcionalidade em sentido estrito) é obrigatória quando uma norma fundamental com caráter de princípio entra em colisão com o princípio oposto, isto é, quando a possibilidade jurídica de realização da norma depende do princípio oposto; b) "os princípios são normas que ordenam que algo seja realizado na maior medida possível, dentro das possibilidades jurídicas e reais existentes" ${ }^{20}$ e daí a sua otimização deve contribuir para alcançar o objetivo perseguido, ${ }^{21}$ e c) a otimização fática deve visar sempre o meio mais benigno, que dizer, sempre deve ser considerado se não estão à disposição outros meios convenientes que prejudiquem menos os afetados e a comunidade, segundo a máxima de Pareto. $^{22}$

O princípio da transparência pode ser entendido como uma 'diretiva' - escolha política do legislador constitucional - uma 'norma - regra' ou uma 'norma princípio', pois tanto é espécie de norma jurídica que prescreve conteúdos direta ou indiretamente relacionados à conduta humana, quanto, muitas vezes, entra em conflito com outras normas - princípios, sendo concretizado em vários graus ou aplicado mediante regras de prevalência. De fato, a expressão 'transparência' se impôs nos últimos anos para qualificar o movimento de abertura da administração para o exterior, suplantando, progressivamente o conceito de publicidade da ação administrativa que vinha sendo utilizado para combater o segredo administrativo arcana imperii. ${ }^{23}$

A idéia de transparência, por corresponder a uma pressão aumentada em relação à Administração, é mais larga e mais exigente que a de publicidade: os cidadãos modernos não obedecem sem conhecer e obedecem com a única condição de consentirem. A partir do momento em que a Administração interfere nos detalhes da vida cotidiana, multiplicam-se as interdições e as regulamentações minuciosas, de modo que os administradores começam a sentir falta de outra coisa mais do que a crença na infalibilidade da sanção ou o respeito pela autoridade suprema, para que

20 ALEXY, (nota 18), p. 86.

21 Robert Alexy assim exemplifica a máxima da necessidade: A norma $\mathrm{N}$ é promulgada pelo legislador tendo em vista aumentar a segurança do Estado (PI), mas atinge a liberade de expressão (P2). Se a norma $\mathrm{N}$ não é adequada para promover $\mathrm{P} 1$ e acarreta perdas para $\mathrm{P} 2$, então existe, neste caso, a possibilidade fática de realizar ambos princípios na maior medida possível, declarando inválida a norma N. In: Derechos, razionamiento jurídico y discurso racional. Derecho y Razón Pratica. México, Fontamara, 1993, p. 32.

22 Pelo critério de otimização de Vilfredo Pareto, uma situação social será considerada ótima se não for possível transferí-la para outra situação onde, no mínimo. um indivíduo experimenta uma melhora e nenhum dos participantes piora. Cf. ALEXY, (nota 18), p. 164. Sobre os três preceitos da proporcionalidade, ver. também MAURER, (nota 4), p. 52.

23 Cf. DEBBASCH, Charles. Introduction In: La Transparence Administrative en Europe. Actes du colloque tenu à Aix en octobre 1989. Paris: Centre National de la Recherche Scientifique. 1990, p. 11 . 
as regras sejam obedecidas: a Administração passa, então, a ter que obter a adesão à regra e isto se faz com um apelo à inteligência e à razão dos cidadãos. ${ }^{24} \mathrm{~A}$ essa idéia de consentimento se junta o princípio do conhecimento, não se aceitando um governo sem conhecê-lo e. por isso mesmo. o conhecimento pressupõe a transparência. Nesse sentido. o princípio da transparência é uma 'diretiva', uma idéia reguladora geral.

A transparência é a abertura da Administração ao administrado, e contém, pelo menos, três aspectos: o primeiro, que diz respeito à publicação das decisões administrativas, responde mais às necessidades de ação do que à idéia de transparência e, nesta acepção é uma 'norma-regra' ${ }^{25}$ o segundo, que é o momento em que a Administração faz conhecer os motivos de sua ação, explica-se e diz porque decidiu, já é o domínio da transparência ("norma-princípio"); o último, e o mais importante, é o diálogo que a Administração estabelece com o cidadão, que se expressa em uma verdadeira participação do particular nas decisões administrativas. Neste caso, a transparência é um dever da Administração e um direito fundamental do cidadão (de terceira geração). ${ }^{26}$

Afirma Debbasch que o princípio da transparência se irradia no conjunto da vida social contemporânea sendo, por exemplo, um dos direitos essenciais dos trabalhadores nas empresas o de serem informados a respeito da situação econômica da empresa e sobre o conjunto das decisões dos dirigentes. Da mesma forma, a reivindicação de transparência se difunde no conjunto da vida política stricto sensu, basta ver as regulações de eleições e do funcionamento dos partidos políticos. "A passagem de uma administração de comando a uma administração de concertação se faz pela intermediação obrigatória da transparência". ${ }^{27} \mathrm{E}$ mais: a ultrapassagem do segredo - regra de ouro do Poder Executivo até um período recente - para a transparência só pode ser explicada pela transformação da atividade da Administração, que se estende e penetra a vida cotidiana, dessacralizando o Poder Executivo, de modo que é em domínios novos - urbanismo, proteção do desenvolvimento que reside o centro dos esforços de transparência. ${ }^{28}$

Aprofundando-se o conceito de transparência, aparecem três facetas diferenciadas. A primeira é que transparência é direito de saber, isto é, se a Administração

24 Cf. RIVERO, Jean. Rapport de Synthèse. In: (nota 23 ), p. 311.

25 Cf. RIVERO, (nota 23). p. 308.

26 Adota-se, aqui, a classificação dos Direitos Fundamentais por gerações. conforme a doutrina alemã, amplamente aceita e difundida : os direitos de $1^{3}$. geração são as liberdades (correspondem a um não-agir do Estado): os de $2^{a}$. geração são os sociais (requerem uma ação positiva do Estado - direitos de exigir): os de $3^{a}$. geração, se é que se pode falar nisso. seriam os direitos de solidariedade, o de viver em um meio ambiente sadio (ecológicos) e o direito à transparência administrativa. Na França. a formulação é um pouco diferente, mas com idêntico conteúdo: direitos fundamentais são tratados todos como 'libertés publiques'. com diferenças de natureza entre duas categorias de direitos: pouvoirs de faire (poderes de agir) - liberdades clássicas - e ponvoirs d'exiger (poderes de exigir) ou direitos de crédito.

27 DEBBASCH. (nota 23). p. 12.

is Cf. RIVERO. (nota 23). p. 311. 
funciona no interesse geral, os cidadãos devem ter o direito de saber o que se passa no interior da Administração porque ela está a seu serviço. O segundo aspecto do princípio da transparência cinge-se ao direito de controle, porque só conhecendo o que se passa dentro da Administração, o cidadão pode melhor verificar a legalidade e a oportunidade das decisões administrativas e apreciar como o dinheiro público está sendo utilizado. Isto responde à idéia, presente nas democracias modernas desde a Declaração dos Direitos do Homem de 1789, de que todo ato político tem que tolerar um controle dos cidadãos. ${ }^{29}$ Por fim, por transparência entende-se o direito do cidadão de ser um ator e não só um espectador da vida administrativa: é o direito de não ser mais um administrado, mas um usuário, isto é, de participar dos mecanismos administrativos. ${ }^{30} \mathrm{~A}$ transparência, então, tende a modificar os procedimentos administrativos e sua efetividade está sujeita a muitas controvérsias, sendo a primeira, de natureza textual: a legislação está adaptada ao princípio da transparência? Qual o conteúdo preciso do preceito? A segunda, é mais de natureza sociológica: os administrados conhecem as técnicas de transparência? $O$ que pode ser feito para melhorar esse conhecimento? A Administração tem a obrigação de pôr ao alcance dos administrados as condições pelas quais se exerce a transparência? A solução de tais controvérsias depende, à toda evidência, da tradição nacional do sistema político e do equilíbrio de poderes e não é idêntica para cada país. "Mas a transparência administrativa se impõe progressivamente. Sem ela, não há mais legitimidade administrativa". ${ }^{31}$

\subsection{Participação pelo Procedimento Administrativo}

Em que pese a noção de ato administrativo ainda ocupar um lugar central na formação do direito administrativo de cada país, o fato é que as insuficiências e

29 Werner Maihofer afirma: “(...)En una república todo acto político tiene que tolerar un control por parte del público, como una suerte de cuarto poder, unicamente por cuya aprobación puede alcanzar legitimidad moral y con ello la legalidad juridica". In: Principios de una democracia en libertad. in: HEYDE, Wolfgang (org.) et alii. Manual de Derecho Constitucional. Madrid: Marcial Pons, 1996, p. 274. Controle é, então, a atividade de fiscalização exercida pelos cidadāos em relação aos atos estatais. Quando o ato é de ordem geral e abstrata, válida igualmente para todos (lei em sentido material), o controle é normativo e se cingirá a verificar se o ato em questão é adequado - em forma e contéudo - à Constituição. É o controle de constitucionalidade. De outra parte, quando o ato estatal é ordem determinada, especial, a fiscalização se restringirá aos aspectos de legalidade (conformaçâo do ato com o ordenamento jurídico em geral) e legitimidade (competência para a prática do ato) e o controle é administrativo a posteriori, quando intenta açāo para ressarcir prejuízo decorrente de execução administrativa.

30 A República Federal da Alemanha constitui um exemplo de concretização da transparência administrativa, mais no que diz respeito ao procedimento, pois o que foi reclamado pelos seus cidadãos, no curso dos anos setenta do séc. XX, foi a "democratização da sociedade" através da participação e não propriamente a transparência administrativa; por isso, a transparència foi concebida como um meio de desenvolver a participação dos cidadāos na ação da Administração e aparece como a "antecâmara" do Estado de Direito.

31 DEBBASCH, (nota 23). p. 14. 
limitações da doutrina clássica fizeram com que essa noção não pudesse mais ser o centro de gravidade da Administração, pois domínios inteiros estão subtraídos da atividade administrativa autoritária e unilateral, de modo que o ato administrativo foi absorvido por formas de atividade cada vez mais complexas e articuladas. A resposta a este problema foi dada pela doutrina italiana, através da revalorização do procedimento, que supera o clássico dilema de saber se o ato administrativo deveria ser concebido à maneira de uma sentença ou negócio jurídico, isto é, uma das 'formas de comunicação entre o poder público e os particulares', ao lado da sentença e da lei. A doutrina italiana seguiu, neste passo, o caminho traçado pelo positivismo jurídico da Escola de Viena, cujos expoentes foram Kelsen e Merkl. Com efeito, a aproximação da função administrativa com a função jurisdicional enquanto funções executivas "lançou os fundamentos teóricos da idéia de alternatividade do procedimento administrativo relativamente ao processo judicial." 32 Transferindo o centro da atenção do ato administrativo em sentido estrito (provvedimento) para o procedimento, a perspectiva, antes jurisdicional - o procedimento explicava a formação da decisão final da Administração, como um instrumento a serviço do ato - foi deslocada para o procedimento, visto de uma forma autônoma. Isso é assim porque, se a Adminsitração, cada vez mais, "privatiza a sua actividade, ou a contratualiza. o valor publicístico dessa actividade não pode mais ser encontrado no seu regime substancial, mas deve ser procurado para além dela e dos seus resultados, isto é, na sua organização." 33

A idéia de processo administrativo ${ }^{34}$ aparece como expressão dinâmica da função, marcando a passagem de uma concepção subjetivística ("manifestação da

32 Cf. PEREIRA DA SILVA, Vasco Manuel Pascoal Dias. Em Busca do Acto Administrativo Perdido. Coimbra: Almedina, 1996, p. 320. Odete Medauar aponta que, na doutrina estrangeira, é atribuído a Merkl o pioneirismo no tratamento da processualidade no direito administrativo, através da obra publicada em 1927; outro momento doutrinário expressivo foi com a obra de Sandulli, editada pela primeira vez em 1940. Também é de 1940 a obra do espanhol Vilar y Romero. Em 1952. Feliciano Benvenutti, vincula a processualidade à função, como sua manifestação sensível. Em 1968, surge na França o livro de Guy Isaac, em que ele defende a visão global do fenômeno processual jurídico, admitindo a processualidade administrativa. Alberto Xavier, em 1976, na esteira de Benvenuti, publica, no Brasil, a obra Do Procedimento Administrativo, em que advoga a noção ampla de processo como expressão de uma vontade funcional. Na doutrina italiana, a obra de Mario Nigro, desde 1953. se dedicou ao procedimento administrativo e, em suas obras posteriores, principalmente nos anos 80, o tema foi acentuado e aprimorado. Gergio Berti, em 1986, realizou estudo sobre o processo, "vinculando a função e ressaltando que processo não é necessariamente ligado à jurisdição, no sentido de que a atividade jurisdicional não tem a exclusividade do processo". In: A Processualidade no Direito Administrativo. São Paulo: Editora Revista dos Tribunais, 1993, pp. 18 e ss

33 Cf. PEREIRA DA SILVA, (nota 32), p. 304.

34 Odete Medauar prefere denominar 'processo' ao procedimento administrativo, explicando que o receio de confusão com o processo jurisdicional deixa de ter razão de ser quando se adota a idéia de 'processualidade ampla', isto é, "a processualidade associada ao exercício de qualquer poder estatal". Mesmo nos países em que se adota o sistema de dupla jurisdição, assevera ela. o termo 'processo' pode ser utilizado na jurisdição administrativa ('processo jurisdicional administrativo') 
vontade da administração") para uma mais objetiva, de modo que, "pelo enfoque da função, entre a norma que atribui o poder e $O$ ato administrativo, se coloca a função e não a autoridade com sua vontade; o ato administrativo é visto, portanto, como produto da função e não como manifestação pré-constituída de um sujeito privilegiado". ${ }^{35}$ Por isso é que, no processo administrativo, Administração e sujeitos se encontram para colaborarem na formação de um ato administrativo que não é mais só a expressão da vontade subjetiva da autoridade, ao contrário: o ato administrativo resulta "de um contraditório entre a Administração e interessados ou de vários interessados ante a Administração, havendo um confronto visível de todos os interesses presentes na situação. É um dos caminhos para a objetivação do poder administrativo." 36

Dada a progressiva aproximação entre a Administração e o cidadão, o procedimento deixa de 'pertencer' à Administração, para tornar-se uma "espécie de "condomínio", em que particulares e autoridades administrativas se tornam "cúmplices" da realização das tarefas administrativas". ${ }^{37}$ Assim, o procedimento acabou por alterar o 'tipo burocrático' de Administração delineado por Weber, que surge hoje profundamente transformado pela participação, implicando uma "verdadeira e própria repartição do poder ("potestade") administrativo entre o titular burocrático formal e a pluralidade dos intervenientes". 38

Por procedimento não se entende somente uma sequiência ordenada de atos em vista de uma medida, mas sobretudo um modo e um método de ordenar os múltiplos

e deixa-se a locução 'processo administrativo' para a esfera da Administração. Em todo o caso, advoga Medauar que a melhor expressão, no Brasil, é 'processo administrativo', porque ela revela que "o procedimento com participação dos interessados em contraditório, ou seja, o verdadeiro processo" também ocorre na esfera da Administração Pública. O legislador constitucional de 1988 adotou a expressão 'processo'em vários dispositivos, assim como o fez o legislador infraconstitucional de 1999. Neste estudo, porém, utiliza-se a expressão 'procedimento administrativo", quando este é tratado de forma geral e abstrata e nas referências à doutrina e legislações estrangeiras. Ao contrário, nas referências à lei brasileira. adota-se terminologia nela contida (processo).

35 Cf.MEDAUAR, (nota 32). p. 12. Até a década de 20 do séc. XX, entre administrativistas, e década de 40, entre processualistas, a idéia de 'processo' vinculava-se, exclusivamente, 'a função jurisdicional do Estado. Dentre os administrativistas, a fim de evitar a confusão entre o modo de atuar da Administração e o modo de atuação do Judiciário, reservou-se para o âmbito administrativo o vocábulo 'procedimento'. Tais posturas podem ser justificadas pela precedência histórica e pela força da construção processual ligada à Jurisdição, pela idéia, presente durante longo tempo, de que a Administração é atividade livre, incompatível com atuações cujo parâmetro seja o 'processo', bem como pela preocupação com o termo final da decisão - o ato administrativo - "sem que a atençāo se voltasse para os momentos que precedem o resultado final." Ligado a esse aspecto, está o zelo doutrinário $\mathrm{e}$ jurisprudencial com a garantia a posteriori dos direitos dos administrados, representada pelo controle jurisdicional. De acordo com Medauar, foi a partir da década de 50 que a idéia de processo apareceu como expressão dinâmica da função, "manifestando a passagem do poder abstrato ao ato administrativo."

36 MEDAUAR, (nota 32), p. 60.

37 PEREIRA DA SILVA, (nota 32), p. 304.

38

Cf. PEREIRA DA SILVA, (nota 32), p. 305. 
interesses e objetivos públicos que são relevantes para diferentes centros de poder. Com isso, o centro de gravidade do direito administrativo se desloca do ato administrativo e sua concepção clássica de resultado conclusivo da atividade de preparação e de elaboração da decisão para o caminho - o iter - mesmo de formação da decisão.

De acordo com a corrente doutrinária italiana mais significativa (Cassesse e Nigro), a nova perspectiva acerca do procedimento apresenta duas vantagens em relação à tradicional doutrina do ato administrativo como centro de gravidade da atuação administrativa. a saber: a) a uniformização do tratamento dogmático da atividade administrativa porque o procedimento constitui um fenômeno comum a todos os domínios da Administração e faz a ponte entre a atuação de gestão pública e gestão privada; b) permite compreender a integralidade da ação administrativa e seu relacionamento com os privados, ao longo do tempo. A perspectiva é, então, como afirma Nigro, de "técnica de diluição do poder e método de coordenação de organizações" ${ }^{39}$ A teoria austríaca e alemã difere um pouco da teoria italiana no sentido de que, para os germânicos, o procedimento é condicionante da decisão final (teoria da decisão). Os italianos integram a decisão no procedimento e, por isso, enxergam, no procedimento, "o novo conceito central da dogmática administrativista", isto é. a nova realidade reconduz tanto "a actuação das autoridades administrativas como dos particulares a esquemas procedimentais, e preconizando a "objectivização" do Direito Administrativo, dado que todos esses sujeitos se encontram a realizar em conjunto a função administrativa". ${ }^{40}$

Já a doutrina germânica considera a 'relação jurídica' como o novo conceito central da dogmática administrativista. e, relativamente ao procedimento, "caminha no sentido da radical "subjectivização" deste, procedendo ao equilíbrio das posições relativas dos particulares e das autoridades administrativas". ${ }^{41}$ É a tese defendida por Fleiner, Bachof, Erichsen, Martens, Haeberle, Henke, Bauer, Achterberg e outros, segundo a qual a relação jurídica administrativa é a ligação entre dois ou mais sujeitos, constituída pelo Direito Administrativo, ou segundo o Direito Administrativo. O conceito de 'relação jurídica' permite explicar fenômenos que vão além do ato administrativo, como os de participação - dos particulares ou outras autoridades públicas - no procedimento, uma vez que este "constitui uma das modalidades de relação jurídica" ${ }^{42}$ A noção do que seja 'procedimento administrativo' é assimilada à de relação jurídica, na medida em que aquele é um instrumento de regulação dessas relações, "cujos intervenientes são chamados a actuar para a defesa de suas posições juridicas substantivas". Ademais, os direitos subjetivos dos indivíduos e dos grupos possuem uma dimensão procedimental cada vez mais importante na Administração moderna (conformadora de infra-estruturas), pois estes têm faculdades de interven-

\author{
Cf. PEREIRA DA SILVA, (nota 32)., p. 305. \\ PEREIRA DA SILVA. (nota 32), p. 310. \\ PEREIRA DA SILVA. (nota 32), p. 310. \\ PEREIRA DA SILVA. (nota 32), p. 161
}


ção e oportunidades de influência no procedimento administrativo. Esta dimensão procedimental dos direitos subjetivos. que fez nascer um verdadeiro status activus processualis, acabou por se constituir em um "princípio estruturador da Administração jurídico-constitutiva", adquirindo diferentes configurações segundo a legislação, a jurisprudência e a doutrina administrativa, conforme suas especificidades próprias. Daí que, ainda que a verdadeira e eficaz proteção jurídica dos cidadãos se dê através dos tribunais, o procedimento se constitui em auxiliar da Administração e em importante instrumento dessa proteção, pois, "quanto mais difícil for a decisão, mais formalizado deve ser o seu procedimento", principalmente quando se tratar de atos administrativos desfavoráveis. Advém daí ser a lei do procedimento alemã a confirmação da tese de Werner (o direito administrativo é o direito constitucional concretizado) porque a Constituição necessita da concretização operada pelo procedimento administrativo a fim de realizar-se 'a partir de baixo', sendo uma espécie de lei fundamental para a Administração e, simultaneamente, uma lei do cidadão, já que este não é um puro objeto do procedimento, mas dele participa de forma ativa. ${ }^{43}$

As várias leis de procedimento administrativo dispõem sobre um conjunto de meios tendentes a realizar o fim de transparência através do procedimento, tais como: - a participação no procedimento dos sujeitos a quem a disposição é destinada a produzir efeitos diretos, isto é, os sujeitos que a lei manda que intervenham ou que podem sofrer um prejuízo importante. A esses sujeitos, deve ser comunicado (pessoalmente ou por outro meio) o início do procedimento, o órgão competente, o objeto do procedimento e o lugar onde se pode conhecer dos atos; - a participação, no procedimento, de todos os sujeitos portadores de interesses públicos ou privados, bem como os portadores de direitos difusos constituídos em associações e comitês. Via de regra, nas referidas leis está prevista a possibilidade de todos os que participam do procedimento de conhecer seus atos (nos limites do direito de acesso) e de apresentar memoriais escritos e documentos. ${ }^{44}$

43 PEREIRA DA SILVA, (nota 32), pp. 325/326 e 330. Franz Mayer chama a atenção para o fato de que, até 1960, a dogmática administrativista alemã ("desenvolvida sempre mais na direção de uma radical conceitualização jurídica") não se tenha questionado sobre o que se podia entender, em definitivo, do ponto de vista científico, por 'Administração' e por 'procedimento administrativo', bem como para a ausência deste tema em obras fundamentais de direito público, como as de W. Jellineck e Forsthoff. Ele ressalta. no entanto. que Lorenz Von Stein já tinha advogado a tese de uma codificação geral do direito administrativo e que as primeiras tentativas legislativas de normatizar em direção a um direito procedimental administrativo unitário não conduziram, contudo, a uma codificação geral do procedimento. Tal codificação - a Lei de procedimento administrativo de 1976 - é fruto da configuração do direito administrativo contemporâneo. que inclui a tendência a uma atuação administrativa transparente, entre outras não menos relevantes. In: La Legge sul procedimento amministrativo nella Repubblica Federale Tedesca. Riv. Trim. Dir. Pub.. Milão: Giuffrè, $n^{\circ} 3,1977$, pp. 1116 e 1117.

44 Os fenômenos procedimentais no direito administrativo podem, segundo Pereira Dias, ser agrupados de acordo com três perspectivas: a) a primeira, negativista, não considera a relevância autônoma do procedimento e continua a analisar o Direito Administrativo do ponto de vista do contencioso: é a visāo que impera na França: b) a segunda, é uma perspectiva maximalista, segundo 
As legislações sobre processo (ou procedimento) administrativo adotadas em vários países ${ }^{45}$ têm finalidades específicas, tais como a garantia jurídica dos administrados (tutela direitos que as decisões administrativas podem afetar), protegendo amplamente os administrados, mediante uma variedade de instrumentos processuais que servem para a melhor defesa de seus direitos; ${ }^{46}$ a ampliação dos pressupostos objetivos dos atos administrativos, lhes emprestando maior eficácia, pois os interessados com eles colaboram, trabalhando com pautas de racionalização, operatividade, ordenação, probidade e moralidade. ${ }^{47}$ Além disso, resulta evidente a finalidade de legitimar o exercício do poder estatal, pois o "objetivo do procedimento juridicamente organizado consiste em tornar intersubjetivamente transmissível a redução de complexidade, quer com a ajuda da verdade, quer através da criação do poder legítimo de decisão" ${ }^{48}$ e levar ao correto desempenho da função administrativa, uma vez que o processo propicia condições para isso, pois "leva ao equilibrio entre a autoridade do sujeito público e os direitos dos particulares" ${ }^{49}$ Isto faz com que a Administração objetive suas decisões, pois estas decorrem de um confronto e, por último, é suscitado "o afloramento de vários interesses, posições jurídicas, argumentos, provas, dados técnicos" obrigando à consideração dos interesses e direitos co-presentes em certa situação". ${ }^{\circ 0}$ Reforçando-se as garantias procedimentais e limitando-se, por essa forma, a discricionariedade administrativa, a Administração

a qual " a afirmação da relevância e autonomia dos fenômenos procedimentais vai dar origem ao surgimento de codificações que, dada a amplitude das matérias tratadas, vão muito além da regulação estrita do procedimento administrativo", chegando a incluir disposiçōes de direito material. Este é o entendimento dominante na Áustria, Alemanha, Espanha, EUA, Portugal e na América Latina em geral (inclusive o Brasil); c) a terceira posição, que é a do direito italiano, é uma perspectiva que se pode chamar 'minimalista', pois, mesmo que seja realçada a importância dos fenômenos procedimentais (o procedimento é considerado o 'núcleo' do direito administrativo), a codificação tem caráter restrito e se limita "a estabelecer princípios gerais ou a regular apenas alguns dos seus momentos considerados mais importantes.Cf. PEREIRA DA SILVA, (nota 32), p. 312.

45 Odete Medauar relaciona as principais leis de processo administrativo de 1889 a 1990 , quais sejam: a lei espanhola de 1889 , a lei austríaca de 1925, a lei norte-americana de 1946 , as leis das democracias populares (Tchecoslováquia, de 1955: Ioguslávia, de 1957, Polônia, de 1960 e Hungria, de 1957), a lei espanhola de 1958, a lei argentina de 1972, a lei alemã de 1976, a lei italiana de 1990, a lei portuguesa de 1991 e alguns textos latino-americanos, como o Dec. 640/73 do Uruguai, a Lei Geral da Administração Pública da Costa Rica, de 1978, a Lei Orgânica de Procedimentos Administrativos da Venezuela, de 1982 e o Código Contecioso-administrativo da Colômbia (país que adota a dualidade de jurisdição), de 1984. A autora não faz referência à lei brasileira de processo administrativo, porquanto a mesma é posterior à edição do texto ora consultado. In: (nota 32), pp. 139 e ss.

46 Cf. MEDAUAR, (nota 32), p. 62 e BARACHO, José Alfredo de Oliveira. Teoria Geral dos Procedimentos de exercício da Cidadania perante a Administração Pública. RDA n 207, jan/mar. 1997 , p. 51 .

47 Cf. BARACHO, (nota 46), p. 51.

48 Cf. MEDAUAR, (nota 32), p. 65.

49 MEDAUAR, (nota 32), p. 66.

50 MEDAUAR, (nota 32), p. 66. 
tende a atuar de maneira correta na prestação dos serviços que atendem necessidades gerais. ${ }^{51}$ Com a 'judicialização' da Administração Pública, Administração e administrados submetem-se à lei e ao Direito, o que garante a regularidade e a racionalidade do poder estatal e do dever particular. ${ }^{52}$

Alcançar a Justiça na Administração também é uma finalidade, porque o processo administrativo garante não só o contraditório e a ampla defesa, como também propicia "o sopesamento dos vários interesses que envolvem uma situação" ${ }^{53} \mathrm{Com}$ isso, há a aproximação entre a Administração e os cidadãos, quebrando-se a tradição de oposição entre interesses públicos e interesses privados. As diversas leis de procedimentos buscam, igualmente, sistematizar as atuações administrativas, uma vez que o processo "implica organização racional da edição de muitos atos administrativos". ${ }^{54}$ Os meios consagrados para a defesa da autoridade, como a presunção de legitimidade, executoriedade, procedimentos reservados, tornam-se mais simples e eficazes. ${ }^{55}$ Por último, as leis tendem a facilitar o controle da Administração, o que se "coaduna à idéia de Administração democrática" ${ }^{56} \mathrm{e}$ a aplicar uniformemente princípios e regras comuns da atividade administrativa, porque o processo tende a ser o ponto de encontro de vários regulações diferentes que presidem à atividade administrativa, concretizando os princípios e regras constitucionalmente consagrados.

O procedimento, por conseguinte, tende a ser um instrumento para a realização da atividade administrativa, pois acaba definindo a própria forma desta, a teor do que ocorre com a função judicial através do processo ou com a função legislativa, por meio do processo legislativo. Daí decorrem, segundo Baracho, ${ }^{57}$ duas consequêencias: a primeira, de o procedimento jurisdicizar a atuação administrativa, "submetendo-a a regra ou pautas formais"; e a segunda, de o procedimento permitir "aos cidadãos conhecer, anteriormente, o desenvolvimento da atuação administrativa, garantindo assim a defesa de seus direitos e interesses frente a ela" ${ }^{58} \mathrm{O}$ procedimento administrativo também é um instrumento de proteção da cidadania e dos direitos fundamentais, de forma que a "garantia jurisdicional do cidadão, nas suas relações com a autoridade administrativa, constitui um dos problemas principais do Estado Democrático de Direito". 59

\footnotetext{
s! Cf. BARACHO, (nota 46), p. 52.

52 Cf. BARACHO, (nota 46), p. 51.

53 MEDAUAR, (nota 32). p. 67.

54 MEDAUAR, (nota 32), p. 68.

55 Cf. BARACHO, (nota 46), p. 51.

56 MEDAUAR, (nota 32), p. 69.

57 BARACHO, (nota 46), p. 53.

58 BARACHO, (nota 46), p. 53.

59 BARACHO, (nota 46). p. 43.
} 


\section{II - Concretizações da transparência administrativa no Brasil}

\subsection{A lei de processo administrativo brasileira}

A lei de processo administrativo brasileira se insere em um quadro de transformação da função administrativa que está ocorrendo nos países ocidentais. Na medida em que se alteram as funções do Estado e da Administração, modificam-se as relações entre Estado e particulares e se alteram as próprias concepções do Direito Administrativo. Este movimento da Administração Pública para o exterior (que, no âmbito deste estudo está sendo chamado de 'princípio de transparência') não prescinde que se extrapole, igualmente, o perfil do processo administrativo ligado somente à dimensão do ato administrativo, para se chegar, como diz Odete Medauar, "até à legitimação do poder". ${ }^{60}$ Isto está ligado à concepção moderna de cidadania. que prevê diversas formas de participação do cidadão na esfera política e, mesmo, na própria Administração Pública, ${ }^{61}$ o que foi chamado por Caio Tácito, de "Direito Administrativo Participativo". ${ }^{62}$

Na sistemática brasileira, o procedimento administrativo é denominado "processo administrativo" tanto na Constituição quanto na legislação ordinária e figura como garantia constitucional, inscrito no inciso LV do art. $5^{\circ}$, que dispõe sobre os Direitos Fundamentais. As Constituições brasileiras anteriores faziam referência expressa tão-somente no que diz respeito ao processo administrativo disciplinar, e as garantias inerentes ao esquema processual "eram extraídas, pela doutrina e jurisprudência, por analogia ou interpretação extensiva, de garantias fixadas pelo processo penal" ${ }^{63}$ ou, por vezes, do sistema constitucional e seus princípios. Na Constituição de 1988. além de estar previsto especificamente o processo administrativo, a ele também se aplica, por força do preceito inscrito no inciso LIV do art. $5^{\circ}$, a cláusula do devido processo de direito (due process of law), fazendo com que o processo administrativo seja um dos meios capazes de concretizar princípios e regras constitucionais. no plano da atividade administrativa.

O processo administrativo, dessa forma, alçado à categoria de garantia dos direitos fundamentais, tende a realizar o princípio democrático, "quando (e onde) possa o administrado participar da feitura do querer administrativo, ou da sua concretização efetiva" ${ }^{6+}$ e, por essa razão, legisladores e juristas não economizaram

60 MEDAUAR. (nota 32), p. 62.

6! Cf.BARACHO, (nota 46), p. 39.

62 CAIO TÁCITO. Direito Administrativo Participativo, RDA no 209, jul-set.1997, pp. 1 a 6 e Transformaçōes do Direito Administrativo. RDA n 214, out-dez. 1998, p. 34.

63 MEDAUAR. (nota 32), p. 73.

64 Para Sérgio Ferraz, embora a formulação da expressão "processo administrativo" seja de " duvidosa técnica" foi consagrada para dar conta de dois fenômenos: a dinâmica da atuação administrativa e o "procedimento que enseja a formulação das opções concretas e/ou políticas administrativas." Até 1988, a sua doutrina era pouca, e a legislação, "parca", encontrando-se o processo administrativo em alguns assuntos específicos, como o contencioso tributário e previdenciário, além da normação do processo administrativo disciplinar. Ainda que os textos constitucionais anteriores 
esforços no sentido de assegurar ao cidadão a possibilidade de postular junto à Administração, com as mesmas garantias que lhe são deferidas no processo jurisdicional (particularmente, as certezas do contraditório, da ampla defesa e da publicidade). A promulgação da Lei Federal n 9.784 , de 29 de janeiro de 1999 é o primeiro resultado desse esforço.

\subsubsection{Os princípios e regras fundamentais da Lei de Processo Administrativo}

Consoante as palavras de seus autores ${ }^{65}$ na Exposição de Motivos, a lei brasileira adotou um modelo sóbrio "que atendendo à essencialidade na regulação dos pontos fundamentais do procedimento administrativo, não inviabilize a flexibilidade necessária à área criativa do poder discricionário, em medida compatível com a garantia de direitos e liberdades fundamentais". ${ }^{66}$ Mas a referida lei é, de qualquer forma, um marco na busca da codificação do direito administrativo brasileiro, tão almejada por Hely Lopes Meirelles, uma vez que firmou como parâmetros básicos os princípios constitucionais da ampla defesa, consagrou o dever de transparência que se manifesta no acesso às informações e na obtenção de certidões e na garantia do direito de petição, além de ter considerado "a missão atribuída à defesa de direitos difusos e coletivos com a participação popular e associativa". ${ }^{67}$

No artigo primeiro, a lei explicita, de plano, suas finalidades, quais sejam: estabelecer normas básicas sobre o processo administrativo no âmbito da Administração Federal direta e indireta, proteger os direitos dos administrados e o melhor cumprimento dos fins da Administração. Os preceitos da lei também se aplicam aos órgãos dos Poderes Legislativo e Judiciário, quando no desempenho de função administrativa, isto é, quando praticam atos materiais de administração. Para além disso, a lei define o que se deva entender por 'órgão', 'entidade' e 'autoridade', bem como estarem os processos administrativos específicos excluídos de seu âmbito de aplicação (art. 60). Resulta daí que ficou ressalvada a eficácia de leis especiais, com a aplicação subsdiária das normas gerais ali inscritas, como as que regulam o processo licitatório, disciplinar ou tributário, de que são exemplos o julgamento de contas de

tivessem consagrado o 'direito de petição' e o 'direito de apresentaçāo' - a serem exercitados pela via do processo administrativo - a doutrina juspublicista se interessava mais pelo exame do ato administrativo do que pela atividade administrativa e o "vé́culo de sua exteriorização - o processo administrativo". In: O processo administrativo e a Constituição de 1988. Revista Trimestral de Direito Público. N$^{\circ} 1 / 93$, pp. 85/86.

65 Comisão de Juristas formada, inicialmente, pelas professoras Odete Medauar e Maria Sylvia Zanella di Pietro. pelos professores Inocêncio Mártires Coetho, Diogo Figueiredo Moreira Neto, Almiro do Couto e Silva, José Carlos Barbosa Moreira, sob coordenaçāo de Caio Tácito, acrescida, em 31 de janeiro de 1996. dos professores Adilson de Abreu Dallari, José Joaquim Calmon de Passos, Paulo Eduardo Garrido Modesto e Carmem Lúcia Antunes Rocha.

66 CAIO TÁCITO. Exposição de Motivos n 548 . de 30 de setembro de 1996. do sr. Ministro da Justiça e da Administração Federal e Reforma do Estado. Arquivos do Ministério da Justiça. Brasília, 49 (188): 225-241. jul./dez. 1996, p. 227.

67 CAIO TÁCITO, (nota 66), p. 226. 
responsáveis por dinheiros públicos, organização da proposta orçamentária e execução do orçamento. que estão reguladas pela Lei de Responsabilidade Fiscal e aplicação das Leis $n^{\circ}$ s 4.320/64 e 6.223 e Decreto-lei ${ }^{\circ} 199 / 67$, no que ainda couber; a autorização e concessão de pesquisa de lavra (Código de Minas); licença para caça (Código de Caça); derivação de águas públicas, aproveitamento industrial e quedas d'água (Código de Águas); justificação e legitimação de terras públicas; licitações para obras e serviços; determinação e exigência de crédito tributário e disciplina dos funcionários públicos, entre outros.

Além disso, do fato de o processo assentar na cláusula do 'devido processo de direito', isto é, ser uma garantia que visa excluir a vontade arbitrária da atuação do poder, decorrem diversos princípios que o informam, tais como: a) princípio garantidor (art. $1^{\circ}$ e art. $2^{\circ}$. caput e inciso VIII ); b) princípio da participação dos administrados nas tomadas de decisões (art. $2^{\circ}$, inciso $\mathrm{X}$; art. $3^{\circ}$, inciso III; art. $5^{\circ}$; todo o Capítulo V: art. 31 - previsão de consulta pública quando a matéria do processo envolver interesse geral -, art. 32, art. 33, art. 35, art. 38. art. 44, art. 46 e art. 58, caput e incisos ); c) princípio da eficácia (art. $1^{\circ}$ ); d) princípio da imparcialidade e objetividade na ação administrativa (art. $2^{\circ}$, parágrafo único, incisos II e III); e) princípio da publicidade dos procedimentos e atos administrativos ( art. $2^{\circ}$, incisos $\mathrm{V}$ e X); $\mathrm{f}$ ) princípio do direito de acesso a documentos e autos, obtenção de cópias ou certidões (art. $3^{\circ}$, inciso II; g) princípio da segurança jurídica (art. $2^{\circ}$, caput, e $54^{\circ}$ - prazo decadencial); h) princípio da não reformatio in peius, no procedimento em via de recurso, sem que o recorrente seja cientificado para que formule suas alegações antes da decisão e nos casos de revisão, quando surgirem fatos novos ou circunstâncias relevantes suscetíveis de justificar a inadequação da sanção aplicada (art. 64, parágrafo único e art. $65^{\circ}$, parágrafo único ); i) princípio da unidade ou da concentração (art.12 e art. 15); j) princípio da obrigatoriedade de concluir o procedimento quando iniciado e mediante ato explícito (art. $49 ; \mathrm{k}$ ) princípio da hierarquia (art. 17 e art. 57); 1) princípio da condenação do silêncio, com sanções (art. $42, \S \S 1^{\circ}$ e $2^{\circ}$ e art. 48 ); m) princípio da legalidade (art. $2^{\circ}$, caput, e inciso I; n) princípio da prefixação de prazos para a conclusão, com consequiências no que diz respeito aos controles de eficiência (arts. $41,42,43,44.49,56, \S 1^{\circ}, 59$, caput e $\S \S 1^{\circ}$ e $2^{\circ}, 62 ;$ o) princípio da obrigatoriedade do contraditório e da ampla defesa (art. $2^{\circ}$, caput e inciso $\mathrm{X}$ e art. $3^{\circ}$. incisos II, III e IV); p) princípio da gratuidade (art. $2^{\circ}$, inciso XI); q) princípio da oficialidade (art. $2^{\circ}$, inciso XII); r) princípio da simplicidade de formas (art. $2^{\circ}$, inciso IX); s) princípio da obrigação de motivar (art. $2^{\circ}$, caput, e inciso VII e todo o Capítulo XII); t) princípio da economia processual (arts. $7^{\circ}$ e $8^{\circ}$ ) e u) princípio do dever de completar a instrução (art. 49). ${ }^{68}$

Princípios gerais que regem toda a atuação administrativa, estão previstos no caput do art. $2^{\circ}$ (finalidade, razoabilidade, moralidade, interesse público, eficiência e dever de proporcionalidade - sentido amplo), no inciso VI (proporcionalidade no sentido de adequação entre meios e fins - stricto sensu) e no inciso IV (atuação

68 CF. MEDAUAR. Odete. O direito adninistrativo em evolução. São Paulo: Editora Revista dos Tribunais. 1992, pp. 212/213 e BARACHO, (nota 46), p. 53. 
segundo padrões éticos de probidade. decoro e boa fé - princípio da moralidade objetiva).

\subsubsection{Participação dos interessados e motivação dos atos administrativos}

Ressalta evidente a importância das disposições da lei federal sobre processo administrativo, principalmente no que diz respeito à participação dos interessados e à obrigação de motivação dos atos administrativos. Quanto ao primeiro aspecto participação - tem-se, em primeiro lugar, que é obrigatória a participação dos interessados no processo administrativo, como tais definidos no art. $9^{\circ}$ : pessoas físicas e jurídicas que o iniciem como titulares de direitos ou interesses individuais ou no exercício do direito de representação; aqueles que, sem terem iniciado o processo, têm direitos ou interesses que possam ser afetados pela decisão a ser adotada; as organizações e associações representativas, no tocante a direitos e interesses coletivos e as pessoas ou as associações legalmente constituídas, quanto a direitos ou interesses difusos. Capazes, para fins de processo administrativo, são os maiores de dezoito anos, ressalvada previsão especial em ato normativo próprio (art. 10).

Só os interessados têm amplo acesso aos autos do processo (dossiers), bem como só eles podem formular alegações, apresentar documentos antes da decisão (art. $3^{\circ}$, II e III) e participar da instrução (Capítulo X). Ademais, só os interessados (administrados que participam do processo) podem praticar atos processuais e receber intimações (Capítulo VIII). No caso de interessados indeterminados, desconhecidos ou com domicnio indefinido, a intimação deverá ser efetuada por meio de publicação oficial (art. $26^{\circ}, \S 4^{\circ}$ ). A lei abre uma exceção, em relação à participação no processo, para aqueles casos em que a matéria do processo envolve assunto de interesse geral, quando, então, o órgão competente poderá, mediante despacho motivado, abrir período de consulta pública, mas o comparecimento do administrado na consulta pública, não lhe confere, por si só, a condição de interessado. A participação através da consulta pública só confere o direito de obter da Administração resposta fundamentada, que poderá ser comum a todas as alegações substancialmente iguais e o de oferecer alegações escritas (art. $31, \S \S 1^{\circ}$ e $2^{\circ}$ ). $\mathrm{O}$ art. 33 , todavia, contém uma cláusula geral no sentido de ser facultado à Administração estabelecer outros meios de participação dos interessados, diretamente ou por meio de organizações e associaçōes legalmente reconhecidas. quando a matéria for relevante. Nesse particular, a lei poderia ter indicado, a título exemplificativo, quais são estas matérias (urbanismo, proteção contra poluição ou sobre a utilização pacífica de energia nuclear), pois a formulação aberta permite que a Administração decida, discricionariamente, quais são estas matérias. Só a concretização da lei em nível estadual e municipal permitirá que se estabeleçam parâmetros para obrigar a Administração a estabelecer outros meios de participação dos interessados.

No que tange ao segundo aspecto - dever de motivação dos atos administrativos - a lei prevê sejam motivados atos que, outrora, não o deviam ser. como, por exemplo, atos que decidam processos administrativos de concurso ou seleção pública (art. 50, inciso III). De fato, a exigência de motivação dos atos administrativos é uma decor- 
rência do Princípio do Estado de Direito, principalmente no que tange ao dever de fundamentação das decisões jurisdicionais. Ora, se a atividade administrativa vem formulada em esquema processual, é evidente que toda e qualquer decisão, emitida em processo administrativo, deve ser motivada, isto é, deve ser explícita, clara e congruente. assim como pode consistir em declaração de concordância com fundamentos de anteriores pareceres, informações, decisões ou propostas, que, neste caso, ficam fazendo parte integrante da decisão. ${ }^{69}$

\subsection{Direito de obter informações e certidões}

É no que diz respeito às informações e dados constantes de arquivos públicos que se expressa, cabalmente, o princípio da transparência administrativa, pois o dispositivo constitucional se dirige inicialmente a todos os órgãos da Administração direta ou indireta, sejam eles federais, estaduais ou municipais, singulares ou coletivos, locais e centrais. Titulares de deveres de informações também são todos os órgãos que desempenham as funções estatais de legislação e jurisdição. Essas informações ou dados podem interessar ao administrado, particular ou funcionário público, podem ser de interesse coletivo ou de interesse geral e, em qualquer dos casos, "a regra jurídica constitucional investe quisque de populo no direito subjetivo público de exigir do órgão público a informação de que necessita". ${ }^{70}$

'Informação', no sentido do texto. é a liberação para $X$ de certo dado em poder de $\mathrm{Y}$, em que $\mathrm{Y}$ é a fonte e $\mathrm{X}$, beneficiário, e pode ser esclarecimento, ilustração ou complexo de atos reunidos. cuja finalidade seja provar a ocorrência de uma certa

69 Motivo é. segundo a tradição juspublicista brasileira. condição de validade do ato administrativo. ou seja. é a situação de fato ou de direito que determina ou autoriza a realização do ato administrativo. Como assevera Hely Lopes Meirelles. "pela motivação, o administrador público justifica sua atuação administrativa, indicando os fatos (pressupostos de fato) que ensejam o ato e os preceitos jurídicos (pressupostos de direito) que autorizam sua prática." O motivo pode vir expresso em lei ou ser deixado ao critério do administrador. No primeiro caso. é vinculado: no segundo. é discricionário quanto à sua existência e valoração. Quando o motivo é vinculado pela lei, o agente, ao praticar o ato. fica na obrigação de justificar a existência do motivo, sem o que o ato será inválido, ou pelo menos, invalidável por ausência de motivação. O Mérito. conquanto não seja um elemento ou requisito para a formação do ato administrativo. deve ser aplicado no tópico relativo ao objeto. dadas suas implicações com o motivo e objeto do ato, assumindo, assim, sua condição de validade e eficácia. O mérito administrativo se consubstancia na valoração dos motivos e na escolha do objeto feita pela Adiministração. Quando autorizada a decidir sobre a conveniência, oportunidade e a justiça do ato a realizar, o merecimento é aspecto pertinente aos atos administrativos praticados no exercício da competência discricionária. Assim, quando, na atuação discricionária, o motivo não for exigido para a perfeição do ato, o agente pode praticá-lo sem motivação; se, entretanto. o fizer. ficará vinculado aos motivos aduzidos, sujeitando-se à obrigação de demonstrar sua efetiva ocorrência. pela incidência da 'Teoria dos Motivos Determinantes' (elaborada pela jurisprudência do Conselho de Estado Francês, funda-se na consideração de que os atos administrativos, quando motivados. vinculam-se, para todos os efeitos de direito, aos motivos expostos) MEIRELLES, Hely Lopes. Direito Administrativo Brasileiro. 22:. Ed. São Paulo: Malheiros, 1997. p. 181.

70 CRETELLA JÚNIOR. José. Comentários à Constituição Brasileira de 1988. Vol. I. Rio de Janeiro: Forense, 1990, p. 418. 
situação. Se o cidadão tiver interesse em informação que conste em dossiê, arquivo ou fichário de órgão público e essa lhe disser respeito, a mesma lhe deve ser fornecida, sob pena de responsabilidade civil e penal. Da mesma forma, deve ser fornecida a informação que diga respeito ao interesse coletivo - interesse de um grupo de indivíduos - ou ao interesse público, que são aqueles interesses gerais que o Estado coloca entre seus próprios interesses, "assumindo-os e colocando-os sob o regime jurídico de direito público, exorbitante e derrogatório do direito comum".71

Os limites do acesso aos dados, no direito brasileiro, residem nas informações ou dados que, uma vez divulgados, podem ocasionar conseqüências graves para a sociedade e para o Estado, tais como aqueles que podem causar dano, coletivo ou individual ou, ainda, aqueles que podem acarretar pânico à sociedade. Daí a ressalva constitucional de sigilo para esses dois casos. Por fim, a segurança do Estado também é "razão suficiente e legal para que sejam negadas informações a respeito de dados constantes de arquivos de órgãos públicos, pois tal divulgação poderia ameaçar a própria estabilidade do Estado". ${ }^{72}$ Os prazos para a prestação das informações é que não foram previstos pela Constituição, deixando-se à lei ordinária a regulamentação dos mesmos, o que foi feito pela Lei $9.507 / 97 . .^{73}$

Os cidadãos brasileiros também podem, independentemente do pagamento de taxas, ${ }^{74}$ obter certidões em repartições públicas e "requerer, observar e reclamar contra autoridade, ou denunciar abusos dela, mediante petição", ${ }^{75}$ isto é, fazer valer contra a autoridade a defesa de seus direitos ou do interesse coletivo. Pelo direito de petição, reconhece-se a todos os cidadãos o direito de ser parte legítima em processos administrativos ou judiciais, destinados a apurar abusos de poder e promover sua responsabilidade, sendo assegurado a todos, lato sensu, e stricto sensu, por lei ordinária, aos servidores públicos estatutários, definindo-se, no direito positivo, como estatuto peculiar ao agente público. Neste último caso, o direito de petição consiste em requerer, representar ou pedir reconsideração à autoridade superior, ou ainda, recorrer das decisões, desde que o servidor observe "as regras do diploma legal a que se encontra sujeito". ${ }^{76}$

71 CRETELLA, (nota 70), p. 419.

72 CRETELLA, (nota 70), p. 421.

73 BRASIL. Lei 9.507, de 12 de novembro de 1997. Regula o acesso a informações e disciplina o rito processual do habeas data. De acordo com o art. $2^{\circ}$, o requerimento deve ser apresentado ao órgão ou entidade depositária do registro do banco de dados e será deferido ou indeferido no prazo de 48 (quarenta e oito) horas. A decisão deve ser comunicada ao requerente em 24 (vinte e quatro) horas e, ao deferir o pedido, o depositário do registro ou banco de dados marcará dia e hora para que o requerente tome conhecimento das informações (art. $3^{\circ}$ ). Informação por correio eletrônico: http://www.senado.gov.br/.

74 Prestação pecuniária devida à pessoa pública, fundada em lei que a determina, para a realização de atividade exercida por esssa pessoa e que interessa, de modo particular, ao obrigado.

75 CRETELLA, (nota 70), p. 426.

76 CRETELLA, (nota 70), p. 427. 
O disposto no inciso XXXIV do art. $5^{\circ}$ também reforça o controle sobre os atos da autoridade pública. pois institui, ao lado das medidas judiciais - mandado de segurança (coletivo e individual) e de habeas corpus - uma possibilidade de controle direto, através do direito de petição, dos atos ilegais e arbitrários (praticados com abuso de poder), isto é, que consistem em lesões frontais aos textos de lei ordinária ou mesmo da Constituição. Ato arbitrário (praticado com abuso ou excesso de poder, isto é, com 'exorbitância' ou 'desvio') é sempre ilegal, porque exercido sem fundamento legal ou acima dos limites fixados pela lei. ${ }^{77}$

Quanto às certidões (públicas ou administrativas) que o cidadão pode obter, podem ser de inteiro teor ou resumidas, desde que retratem o original do qual foram extraídas. Uma vez autenticada, a certidão tem força probatória de fatos ou situaçōes de interesse do requerente. Aliás, instituído através da Constituição o processo administrativo. o direito de obter certidões abrange os atos administrativos de qualquer tipo, inclusive os pareceres e as informações. Nestes casos. a vista do processo é concecida ao requerente ou a quem tenha fundado interesse e deve ser fornecida na própria repartição, sob o controle da autoridade. De outra parte, quando o requerente é parte no processo administrativo (ou possui um interesse qualificado), "deverá ficar ciente dos despachos e informações através de qualquer forma de comunicação, porque sem a referida ciência pelo interessado, o despacho é ineficaz para a defesa de direitos". ${ }^{78}$ Somente se admite a negativa da autoridade em fornecer a certidão se ao requerente faltar legitimidade (ou interesse qualificado), por falta de vínculo entre o conteúdo do ato certificável com o direito deduzido ou a ser deduzido em juízo ou ainda, por razões de sigilo.

O habeas data ${ }^{79}$ criação da Constituição de 1988 . erigido à categoria de direito fundamental sob forma de garantia processual, tende a ser o recurso judicial para a obteção de informações relativas à pessoa, constantes de registros ou banco de dados de entidades governamentais ou de caráter público, e também para a retificação de dados, caso o cidadão não prefira fazê-lo por processo sigiloso. judicial e administrativo. ${ }^{80}$ Sendo instrumento de garantia de direitos e liberdades - direito subjetivo público posto à disposição do interessado -, foi dotado de "plena, completa e irrestrita eficácia" ${ }^{8 l}$ Várias normas constitucionais são dedicadas ao recurso, como a sua gratuidade e os tribunais competentes para julgá-lo, conforme o caso (art. 102, I, "d"; art. 102, II, "a": art. 105, I, "b"; art. 108, I, "c"; art. 109, VIII e art. 121, $\left.\S 4^{\circ}, \mathrm{V}\right){ }^{82} \mathrm{O}$ writ do habeas data aparece. então, configurado na Carta Magna com

77 Cf.. CRETELLA, (nota 70), pp. 428/429.

78 CRETELLA, (nota 70), p. 430.

79 Habeas data. em sentido literal, significa "toma os dados que estão em seu poder e entrega-os ao interessado", como assevera Cretella $\mathrm{Jr}$

so CRETELLA JÚNIOR, José. Os "writs" na Constituição de 1988. Rio de Janeiro: Forense Universitária, 1989,p. 114

81 Cretella Júnior. assegura que foi o Serviço Nacional de Informações (SNI) e seu completo banco de dados a força-motriz que levou os constituintes à criação do instituto. In: (nota 80), p. 117.

8. Cf. CRETELLA. (nota 80) pp. 116/117. 
a conotação de "instrumento constitucional" através do qual o cidadão pode exigir o "conhecimento de registros e dados relativos à sua pessoa e que se encontrem em repartições públicas ou particulares acessíveis ao público", solicitando, se for o caso, a sua retificação: ${ }^{83}$ sua natureza jurídica é de ação civil especial, os dados devem ser fornecidos no prazo de lei, sob pena de responsabilidade, e a entidade, detentora dos dados, "não é obrigada a fornecê-los, se o sigilo correspondente for imprescindível à segurança do Estado e da sociedade". ${ }^{84}$

São sujeitos passivos de habeas data, conforme o art. $1^{\circ}$ da Lei $9.507 / 97,{ }^{85}$ além das entidades governamentais, quaisquer entidades que, através de registros públicos ou banco de dados, possam fornecer informações sobre a pessoa, isto é, de 'caráter público'. O que importa, na formulação legal, é a condição de que tais informações possam ser transmitidas a terceiros "ou que não sejam de uso privativo do órgão ou entidade produtora ou depositária das informações", isto é, a comunicabilidade a terceiros: "se a entidade se cinge a coligir e armazenar os dados para seu próprio e exclusivo uso, não infringirá a Constituição caso negue à pessoa de quem se trata o acesso ao conteúdo dos registros ou bancos" ${ }^{86}$ Entidades privadas de caráter público, passíveis de serem acionadas pela via do habeas data, são, por exemplo, os serviços de proteção ao crédito, "cujos registros naturalmente se destinam à orientação dos respectivos usuários" ${ }^{87}$ Legitimados ativamente para a ação são as pessoas físicas e jurídicas, tendo a jurisprudência afirmado o caráter personalíssimo da garantia e excluído a possibilidade de exercício por substituto processual ou por ação coletiva. ${ }^{88}$

A Lei ordinária, além de prever a obrigatoriedade da tentativa extrajudicial de obter as informações ou dados (arts. $2^{\circ}$ a $4^{\circ}$ ), de forma que a petição inicial seja instruída com a prova da recusa em atender o requerimento sob pena de indeferimento liminar, ampliou o âmbito da ação, ao prever que ela possa ser impetrada também para " anotação nos assentamentos do interessado, de contestação ou explicação sobre dado verdadeiro não justificável e que esteja sob pendência judicial ou amigável", conforme inciso III do art. $7^{\circ}$. Assim, esgotadas as tentativas e os prazos extrajudiciais, o impetrante, instruindo a petição inicial com a prova da recusa ao acesso às

\section{CRETELLA, (nota 80), p. 122.}

84 CRETELLA, (nota 80), p. 122.

85 Antes da edição da Lei 9.507/97, na falta de disposição infraconstitucional específica, foram utilizadas as normas relativas ao mandado de segurança para o processamento e julgamento do habeas data, de forma que alguns autores, como Cretella Júnior e Manoel Gonçalves Ferreira Filho argumentaram ter sido desnecessária a criaçâo de um remédio novo para tutelar o direito à obtenção e ratificação de dados e/ou informações.De qualquer modo, a considerar-se que a ação pode ser proposta por entidades não governamentais, resta evidente que seu âmbito de aplicação é mais largo do que o do mandado de segurança, impetrado contra "ato de autoridade." Cf. BARBOSA MOREIRA, (nota 14) pp.47 e ss; CRETELLA, (nota 80), p. 119

86 BARBOSA MOREIRA, (nota 14 ), p. 52.

87 BARBOSA MOREIRA, (nota 14), p. 52.

88 Para Barbosa Moreira, tal entendimento está consubstanciado na decisão TRF - 4 R., 15.8.1991, HD n' 0409112. O autor se refere, ainda, à posição de alguns juristas, como Othon Sidou e Luis Afonso da Silva, segundo a qual as informaçōes devem ser prestadas não só ao invíduo uti singuli, mas também às "demais pessoas sob sua dependência familiar". In: (nota 14), p.55. 
informações ou do decurso de mais de dez dias sem decisão, da recusa em fazer-se a retificação ou da recusa em fazer-se a anotação a que se refere $o \S 2^{\circ}$ do art. $4^{\circ}$ (anotação da explicação ou da contestação que justifique possível pendência sobre o fato objeto do dado, ainda que não se constate a sua inexatidão) ou decurso de mais de quinze dias sem decisão, poderá requerer ordem de habeas data destinada a dar a conhecer ao requerente os dados constantes do registro ou banco, a retificação dos dados porventura inexatos ou, ainda, a anotação de explicação ou contestação. O juiz, julgando procedente o pedido. marca dia e hora para que o impetrado apresente as informações, no primeiro caso, ou apresente em juízo a prova da retificação ou da anotação feita nos assentamentos do impetrante. ${ }^{89}$

Em que pesem as dificuldades de processamento do recurso, as semelhanças com o procedimento do mandado de segurança e a discussão sobre a natureza da sentença. concessiva ou denegatória do habeas data ${ }^{90}$ o certo é que o mesmo se vem firmando como o instrumento capaz de obrigar as entidades governamentais e não governamentais de caráter público a fornecer e retificar dados relativos aos cidadãos. que constem de seus arquivos/cadastros, sendo a primeira concretização da transparência administrativa no Brasil, que. nesse particular, segue uma direção já existente em outros países desde a década de 70 , como a Alemanha, através da lei federal de 27 de janeiro de 1977, ${ }^{41}$ e a França, através da Lei ${ }^{0} 78-17$, de 6 de janeiro de 1978, relativa à informatica, aos fichários e às liberdades. ${ }^{92}$

89) Tal sistemática processual põe o problema de se saber se um mesmo processo pode perseguir ambas as finalidades. eis que a lei ordinária não esclarece "como se há de acudir tal emergência". e há uma "prioridade lógica" da decisão sobre o pedido de informaçōes sobre a que examina as objeções à respectiva exatidão dos dados. Barbosa Moreira. no texto consultado. entende que seria um "despropósito" atribuir ao interessado o ônus de impetrar novo habeas data para pedir, dessa vez. a retiticação e/ou a anotação e, por isso, advoga a tese de que o impetrante possa cumular os pedidos no requerimento inicial. Desta forma. em caso de ser assegurado ao impetrante a exibição dos dados. uma vez exibidos estes, o processo deve prosseguir. para o fim de ser retificado o assentamento ou nele ser inserida explicação ou contestação, com a repetição das providências necessárias para assegurar o contraditório sobre o novo tema. "à feição do que ocorre no processo da ação de prestação de contas" mesmo com a manifesta desvantagem de poderem ser prolatadas duas sentenças. Cf. BARBOSA MOREIRA. (nota 14), pp. 56/57.

9) Cf. Barbosa Moreira. a sentença de procedência seria mandamental na hipótese da letra "a" do dispositivo constitucional e constitutiva na da letra " $b$ " (caso de retificação). In: (nota 14). p. 59. 91 A Bundesdatenschutzgesetz consagra a possibilidade de toda pessoa obter comunicação dos dados relativos à sua pessoa que constem em bancos de dados públicos. Tal comunicação está excluída em certos casos, como os de investigação criminal. e. ainda assim. os tribunais entendem que tal comunicação é possível desde que a Administração exerça seu poder discricionário em conformidade aos princípios gerais de direito. procedendo a um balanço dos interesses em causa em respeito ao princípio da proporcionalidade. Cf. FROMONT. Michel. La Transparence Administrative én République' Fédérale d'Allemagne. In: (nota 23).p. 146.

92 Ver: ROUX. André. La Transparence Administrative en France, (nota 23), p. 69 e BARBOSA MOREIRA. (nota 14), p.50. informando sobre a existência de regulação similar na Itália (Lei $\mathrm{n}^{\circ}$ 675. de 31.12.1996). na Espanha e em Portugal, cujas disposições sobre acesso a dados pessoais constam das Constituições, nos arts. 18. 4 e 105. "b" c arts. 26. 2 e 35. respectivamente. 


\subsection{A lei de responsabilidade fiscal}

A Lei de Responsabilidade Fiscal - Lei Complementar 101/2000 - é a regulamentação do art. 163 da CF, ao dispor sobre os princípios e normas de finanças públicas e estabelecer um "regime de gestão fiscal responsável". Por esta locução, segundo o que se depreende do texto legal, entenda-se o estabelecimento de limites aos gastos públicos, que evitem deficits excessivos e reiterados ao longo do tempo. A referida lei faz parte de um projeto maior de reforma do Estado brasileiro, que inclui, entre suas diretrizes, introduzir um regime fiscal sustentável a médio e longo prazos, isto é, insere-se no plano maior de uma ampla reforma tributária.

Afirma Almiro do Couto e Silva ${ }^{93}$ que a noção de responsabilidade do gestor público decorre da própria noção de "Função Administrativa Pública", pois esta pressupõe o planejamento como critério de racionalidade, isto é, o gestor público deve cuidar (administrar) do que é de todos, perseguindo o máximo de resultados com um mínimo de investimentos (princípio da eficiência). A Lei de Responsabilidade Fiscal, então, veio a aprofundar a racionalidade de toda atuação administrativa, no sentido de que haja uma boa e responsável gestão. Além disso, a lei, ao trazer definições novas, como o de 'transparência na gestão fiscal', persegue uma mudança de mentalidade do administrador público, na medida em que configura um sistema de planejamento, execução orçamentária e disciplina fiscal, objetiva controlar o déficit público para estabilizar a dívida a um nível suportável para as economias emergentes, aglutina vários ramos do direito público, pois trata de Direito Financeiro, Tributário, Administrativo e Orçamentário e, o mais importante, estabelece a responsabilização pessoal dos governantes pelo seu descumprimento, conforme $\S 1^{\circ}$ do art. $1^{\circ} .{ }^{94}$

Relativamente ao âmbito de aplicação, estão sujeitos ao regime da lei a União, os Estados, os Municípios, o Distrito Federal, os órgãos dos Poderes Legislativo (inclusive os Tribunais de Contas), o Judiciário e o Ministério Público, organizados em cada esfera de poder. A lei alcança igualmente as respectivas administrações diretas, fundos, autarquias, fundações e empresas estatais dependentes $\left(\$ \S 2^{\circ}\right.$ e $3^{\circ}$ do art. $1^{\circ}$ ). Do alcance da lei estão excluídas, por conseguinte, as empresas estatais independentes, isto é, as que não tomam recursos públicos. O referido diploma legal, por esta via, respeita o federalismo, porquanto é uma lei de regras gerais, deixando para os Estados e Municípios definirem exatamente quais são as normas específicas e os limites específicos que cada um observará, a partir de decisões locais ou estaduais. $^{95}$

93 COUTO E SILVA. Almiro. Responsabilidade Fiscal e Direito Administrativo. Porto Alegre, Assembléia Legislativa, 18 de agosto de 2000. Registro do Seminário "Lei de Responsabilidade Fiscal - Um novo desafio para o Administrador Público", promovido pela Associação dos Procuradores do Estado do Rio Grande do Sul.

94 Cf. PELICIOLI, Ângela Cristina. A Lei de Responsabilidade Fiscal - Uma Abordagem Panorâmica, Evento indicado na nota 93.

95 Como toda lei nova, ainda é difícil avaliar o impacto que a Lei Complementar causará na 
A lei, por outro lado, além de trazer incongruências no seu texto, v.g., o art. 46, de "difícil intelecção", 96 trará dificuldades na responsabilização dos agentes políticos, uma vez que dispõe serem estes puníveis de acordo com a legislação penal, a Lei da Ação Popular, Lei 1.079/50, Decreto Lei 201/67 (sobre a responsabilidade de prefeitos e vereadores) e Lei de Improbidade Administrativa, sem que se tenham unificado, em todos esses textos legislativos, os prazos prescricionais e decadenciais. Isto compromete o princípio da segurança jurídica, assegura Almiro do Couto e Silva, porque o agente político restará sujeito à responsabilização por má gestão fiscal por cinco anos, se configurada a hipótese da ação popular - ato lesivo ao patrimônio público, à moralidade administrativa, ao meio ambiente e ao patrimônio histórico e cultural - por cinco anos, se for o caso em que se configure enriquecimento ilícito no exercício de mandato, cargo ou emprego na Administração Pública direta, indireta ou fundacional ou, ainda, por vinte anos, se for a hipótese de responsabilidade causada por danos ao meio ambiente, ao consumidor, a bens e direitos de valor artístico, estético, histórico, turístico e paisagístico, e a qualquer outro interesse difuso ou coletivo, bem como por infração à ordem econômica e à economia popular.

Quanto à previsão contida no art. $4^{\circ}, \S 1^{\circ}$, da obrigatoriedade de o projeto de lei de diretrizes orçamentárias conter 'Anexo de Metas Fiscais', no qual deverão ser estabelecidas metas anuais relativas a receitas, despesas, resultados nominal e primário e montante da dívida pública para o exercício a que se referirem e para os dois seguintes e 'Anexo de Riscos Fiscais', com avaliação dos passivos e riscos, e especificação das políticas monetárias e creditícias, tudo isso é uma realização indireta da transparência administrativa, porque permitem ao cidadão conhecer e

Administração Pública como um todo, até porque muitas de suas disposições podem ser questionadas no STF, através de Ações de Inconstitucionalidade, tais como o preceito do art. $9^{\circ}, \S 3^{\circ}$, que prevê, no caso de os Poderes Legislativo e Judiciário e o Ministério Público não promoverem a limitação de empenho e movimentação financeira. segundo os critérios fixados pela lei de diretrizes orçamentárias, o Poder Executivo estará autorizado a fazê-lo, isto é, a limitar os valores financeiros segundo tais critérios. $O$ argumento que sustenta a ação é o de que este dispositivo legal fere o princípio da separação harmônica e independência dos poderes. consagrados no art. $2^{\circ}$ da CF. Outro questionamento possível é a violação do princípio da igualdade. porque o art. 63 das Disposições Finais e Transitórias da LRF faculta aos municípios que tenham população inferior a 50.000 (cinquienta mil) habitantes optar por não realizar a verificação do cumprimento dos limites estabelecidos para a redução das despesas com pessoal, a cada quadrimestre, não os sujeitando, por via de consequiência, às sanções previstas no parágrafo único do art. 22 (proibição da concessão de aumentos, vantagens ou reajuste aos servidores, salvo sentença judicial, determinação legal ou contratual; de criação de cargo ou função, de alteração de estrutura de carreira que implique aumento de despesa; de provimento de cargo público, admissão ou contratação de pessoal, salvo a reposiçāo decorrente de aposentadoria ou para atender necessidades coletivas básicas, como educação, saúde e segurança e de contratação de horas extras, excetuando-se as situações previstas na Constituição e na Lei de Diretrizes Orçamentárias).

96 "É nulo de pleno direito ato de desapropriação de imóvel urbano expedido sem o atendimento do disposto no $\S 3^{\circ}$ do art. 182 da Constituição, ou prévio depósito judicial do valor da indenização." Almiro do Couto e Silva dia residir a dificuldade no fato de que parece não se ter o legislador dado conta de que o ato admin:strativo de desapropriação é ato final, para cuja perfectibilização o pagamento da justa indenização (administrativa ou judicial) é condição necessária. In: (nota 93). 
controlar a gestão dos 'dinheiros' públicos até mesmo da Ação Popular, se for o caso. Já a previsão contida no $\S 4^{\circ}$ do art. $9^{\circ}$, é uma realização direta da transparência, porque dispõe a obrigação de o Poder Executivo demonstrar e avaliar o cumprimento das metas fiscais a cada quadrimestre, em audiência pública, na Comissão mista permanente de Senadores e Deputados ou equivalente nas Casas Legislativas estaduais e municipais.

Finalmente, o Capítulo IX da Lei de Responsabilidade Fiscal, concretiza diretamente a transparência administrativa, porque, além de caracterizar a transparência como "ampla divulgação, inclusive em meios eletrônicos de acesso ao público" (art. 48, caput), estabelece os meios através dos quais se pode assegurar a transparência da gestão fiscal, tais como o incentivo à participação popular e realização de audiências públicas durante os processos de elaboração e de discussão de planos, leis de diretrizes orçamentárias e orçamentos (parágrafo único do art. 48), a disponibilização das contas apresentadas pelo Chefe do Poder Executivo, durante todo o exercício, no respectivo Poder Legislativo e no órgão técnico responsável pela sua elaboração, de forma que sejam consultadas e apreciadas pelos cidadãos e instituições da sociedade. A transparência passa a ser, desta forma, um dos princípios fundamentais da Lei Fiscal para o controle das despesas e do déficit público, já que adota medidas de transparência das contas públicas na aplicação e divulgação dos resultados alcançados, como, por exemplo, a obrigatoriedade de apresentar demonstrativos, o que, por si só, já assegura melhoria nesses resultados, como o comprova a experiência internacional. ${ }^{97}$ Em última instância, só através da transparência - apresentação de dados consistentes e compreensíveis, oportunos e atualizados - que se expressa através da obrigação de as autoridades públicas, em cada nível de Governo, emitirem declarações mensais, trimestrais e anuais de responsabilidade fiscal, atendendo aos limites previstos nas metas e objetivos ou justificando seus desvios temporários e, ainda, permitirem o acesso público a essas informações, é que os objetivos da Lei podem ser alcançados. Por outro lado, a efetividade da Lei Fiscal será assegurada por mecanismos de compensação e de correção dos desvios, e com transparência, a fim de punir a má gestão mediante a disciplina do processo político.

\section{Conclusão}

Em síntese, relativamente aos três aspectos da transparência e extensões de sua possível realização, o primeiro - direito de saber/direito de acesso aos dossiers

97 O controle e fiscalização da gestão contábil será feito pelo Poder Legislativo, diretamente ou com o auxílio dos Tribunais de Contas e pelo controle interno de cada Poder e do Ministério Público, não estando previsto nenhum tipo de participação da sociedade, através de suas entidades representativas, neste controle ou mesmo na fiscalização. O que está previsto, no art. 67 das Disposições Finais e Transitórias, é a participação de entidades técnicas representativas da sociedade em um 'conselho de gestão fiscal', do qual devem também fazer parte representantes de todos os Poderes e esferas de Governo e do Ministério Público e cujas atribuições são acompanhar e avaliar, de forma permanente, a política e operacionalidade da gestão fiscal. 
administrativos - foi delimitado pela Constituição Federal Brasileira, estando também configurado na Lei de Responsabilidade Fiscal e na Lei Federal de Processo Administrativo; o segundo - direito de controle - , se concretiza na existência de vários remédios processuais adequados para verificar a legalidade e a oportunidade das decisões administrativas, bem assim a maneira como o dinheiro público está sendo utilizado. A obrigação de motivar os atos administrativos, constante da Lei Federal de Processo Administrativo, facilita o acesso à marcha intelectual da Administração. Finalmente, em relação à realização mais forte da transparência - $a$ participação nos mecanismos da Administração - além de estar delineada na Constituição e Lei de Responsabilidade Fiscal (fase de formulação da proposta orçamentária) está concretizada, pelo menos em linhas gerais, na Lei Federal de Processo Administrativo.

A lei de processo administrativo é, efetivamente, um marco na concretização do Princípio da Transparência, porque contém direito administrativo material e processual e aponta para uma codificação geral do direito administrativo, Contudo, considerando que a competência para legislar em matéria de direito administrativo é privativa ${ }^{98}$ nas três esferas de poder, é imprescindível, para sua efetividade, que Estados e Municípios também regulem o processo administrativo em âmbito local, porque, do contrário, ela se esvaziará. Nada impede que Estados e Municípios aprofundem as diretrizes contidas na lei, ${ }^{99}$ adaptando-as às matérias que são de sua competência (residual e de interesse local), tais como a organização do serviço de transporte coletivo e de passageiros nos limites do território do Município (art. 30, $\mathrm{V}$, da $\mathrm{CF}$ ). relativas aos planos diretores, contendo política de desenvolvimento e de expansão urbana, especialmente planejamento do uso, parcelamento e ocupação do solo urbano (art. 30, VIII, c/c art. 182). Os Municípios e Estados podem também ser agentes ativos no resgate das práticas democráticas, disciplinando a participação popular pela aplicação de regras concernentes ao processo administrativo também na organização de Conselhos Populares, como é o caso do Município de Porto Alegre, que conta com Conselhos Populares, regidos pela Lei Complementar 267 e leis respectivas. Atualmente, existem o Conselho de Contribuintes, o Conselho da Criança e do Adolescente e os Conselhos Tutelares, estando em projeto a criação de um Conselho Municipal de Administração. A semelhança de todos é a composição, no

93 Cf. SUNFELD, Carlos Ari. Sistema Constitucional de Competências. RTDP, n 1/93, p. 274, é da competência legislativa privativa de cada ente federado a organização da Administração Pública, isto é, a edição de leis dispondo sobre a estruturação da Administração, com sua divisão em órgāos ou pessoas jurídicas, a organização dos seniços públicos, os procedimentos a serem adotados no exercício das atividades administrativas e o regime juridico dos servidores.

99 Cf. SUNFELD, (nota 98), p. 275, nos temas de competência privativa, a lei deve ser editada pela pessoa política a quem tiver sido outorgada tal atribuição. Entretanto, em algumas hipóteses, como a regulação da atividade administrativa dos Estados ou Municípios, pode a lei federal ser suplmentada por lei estadual ou municipal, "para o fim específico de submeter o serviço a imposições mais rígidas do que as constantes da norma federal". Da mesma forma, Estados e Municípios estão obrigados a exercer atribuições cuja regulamentaçâo pertence à União, como é o caso das diretrizes e bases da educação nacional e das normas gerais de licitações e contratos administrativos. 
mínimo paritária, entre membros do Poder Público e da sociedade civil, sendo que. em muitos deles, a sociedade civil é majoritária. Há possibilidade de deliberação sobre as políticas públicas a serem desenvolvidas em cada área de atuação, bem como a deliberação das entidades que poderão desenvolver parceria com o Poder Público. Assim. compete aos Conselhos analisar os projetos apresentados pelas entidades, avaliar o grau de carência das respectivas regiões, bem como aprovar os termos da parceria a ser efetivada. Todos os recursos decorrentes de subvenções sociais são utilizados desta forma no âmbito do Município. $O$ aprofundamento e a aplicação do esquema processual à atividade administrativa tende a unificar e disciplinar a atuação de tais órgãos participativos. Se esta participação realmente se concretizará e se tornará efetiva em todos os níveis de Governo, ainda é uma questão em aberto, dependendo mais da ação do conjunto da sociedade do que de leis. 


\section{Regime Jurídico da Proteção às Minorias nas S/A}

Waldirio Bulgarelli

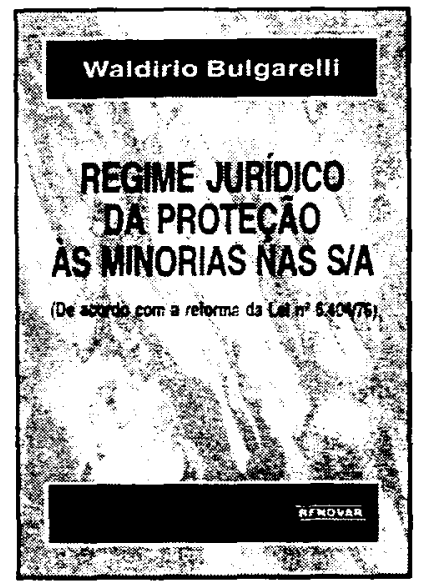

Este livro decorre, em grande parte. da ediçāo anterior publicada em 1977, sob o título A Proteçào às Minorias na Sociedade Anônima, - logo após a promulgação da Lei 6.404/76 que revogou o Dec.-Lei 2.627/1940. O tempo decorrido e as transformaçōes sócio-econômicas e políticas, sofridas nesse período, acrescidas das al teraçōes introduzidas na Lei 6.404/76 - como a Lei Lobão e a manutenção apenas das ações nominativas - culminando, agora, com as inúmeras modificaçōes trazidas pela Lei $9.457 / 97$, implicaram na tarefa de revisar as idéias então expostas e atualizar os dispositivos legais mencionados.

Ref. 0167

Form. 14x21

Brochura

1998

416 págs.

\section{Regime Jurídico do Conselho Fiscal das S/A}

Waldirio Bulgarelli

A lei $9.457 / 97$ trouxe várias alteraçōes na Lei $6.404 / 76$ que rege as sociedades por ações, tendo inclusive, incluído outras alterações no texto da Lei 6.385/78 que regula a Comissão de Valores Mobiliários. O autor dedicou alguns dispositivos ao Conselho Fiscal, embora restritos à remuneração (art. $162, \S 3^{\circ}$ ) e ao pedido de informaçōes sobre fatos específicos (art. $163, \S 4^{\circ}$, ao que acresceu o $\$ 8^{\circ}$ ).

$\begin{array}{lll}\text { Ref. } 0165 & \text { Brochura } & 422 \text { págs. } \\ \text { Form. } 14 \times 21 & 1998 & \end{array}$

Waldrio Bulgarelli

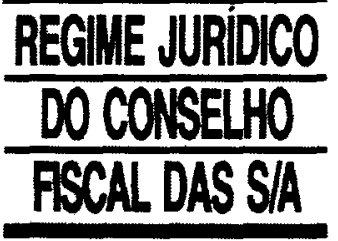

